\title{
Anisotropic fibre-reinforced plastics as formworks for single and double-curved textile reinforced concrete
}

\author{
Henrik L. Funke ${ }^{1}$, Sandra Gelbrich ${ }^{1}$, Andreas Ehrlich ${ }^{1}$, Lars Ulke-Winter ${ }^{1} \&$ Lothar Kroll $^{1}$ \\ ${ }^{1}$ Institute of Lightweight Structures, Technische Universität Chemnitz, Chemnitz, Germany \\ Correspondence: Henrik Funke, Institute of Lightweight Structures, Technische Universität, Chemnitz, Germany, \\ Tel: 0049-371-53138995. E-mail: henrik.funke@mb.tu-chemnitz.de
}

Received: September 5, 2014 Accepted: October 17, 2014 Online Published: November 24, 2014

doi:10.5539/jmsr.v4n1p36

URL: http://dx.doi.org/10.5539/jmsr.v4n1p36

\begin{abstract}
A new constructive and technological approach was developed for the efficient production of large-dimensioned, curved freeform formworks, which allows the manufacturing of single and double-curved textile reinforced concrete elements. The approach is based on a flexible, multi-layered formwork system, which consists of glass-fibre reinforced plastic (GFRP). Using the unusual structural behavior caused by anisotropy, these GFRP formwork elements permit a specific adjustment of defined curvature. The system design of the developed GFRP formwork and the concrete-lightweight-elements with stabilized spacer fabric was examined exhaustively. Prototypical curved freeform surfaces with different curvature radii were designed, numerically computed and produced. Furthermore, the fabric's contour accuracy of the fabric was verified, and its integration was adjusted to loads.

The developed textile reinforced concrete (TRC) had 3-point bending tensile strength of 41.51 MPa. Beyond that, it was ensured that the TRC had a high durability, which has been shown by the capillary suction of de-icing solution and freeze thaw test with a total amount of scaled material of $1172 \mathrm{~g} / \mathrm{m}^{2}$ and a relative dynamic E-Modulus of $100 \%$ after 28 freeze-thaw cycles.
\end{abstract}

Keywords: anisotropic formworks, textile- reinforced concrete, fibre-reinforced plastics, curved concrete

\section{Introduction}

Research in the fields of innovative concrete structures with high potential for lightweight design, and of textile reinforcement for special applications has been object of intensive scientific and application-oriented efforts for a couple of years (Curbach \& Scheerer, 2001; Brameshuber, 2006; Funke et al., 2014a). There is a lack of appropriate formwork systems to implement light shell structures of this kind, with the need for flexibly moldable, reusable systems being particularly tense (Hofstadler, 2008). Textile reinforced concrete offers a high range of variation and thus facilitates a flexible adjustment of the form and textile reinforcement (cf. e.g. (Curbach \& Jesse, 2009) and the citations listed there). Another advantage in comparison to ordinary reinforced concrete is that corrosion can be largely excluded. In this way, filigree constructions of minimal thickness can be realized (Funke et al., 2014b; Greiner, 2007; Funke et al., 2013).

A crucial technological objective of textile reinforced concrete elements is the development of complex solid preform-structures. These are produced by processing flat structures through appropriate cutting (Curbach et al., 2003). The soft-elastic behavior of the 3D-textiles can be influenced to a large extent by modifying parameters such as stiffness, alignment and concentration of pile threads. In this way, it can be adjusted to the defined curvature. Although selectively deformable textile 3D-structures, for instance spacer fabric, for the reinforcement of concrete lightweight elements exist, the corresponding formwork elements are only in an early stage of development. These elements are essential for the realization of concrete shell structures that can be curved in any way.

Currently, the only possible shapes of shell structures are that of domes, hyperbolic paraboloids and conoids. Their production furthermore entails a considerable amount of material and high costs (Hofstadler, 2008; Preisinger et al., 2005; Herzog \& Moro, 1992). Also the mathematical description of the predetermined complex freeform surfaces and the anisotropic material characteristic is difficult (Kroll, 2013, Kaufmann, 2014). In the field of computer-aided visualization, different methods have been developed for the shape optimization of surfaces and their static construction calculation and design. However, these technologies are until now not applied in formwork production (Dallinger et al., 2009). Among the common formwork techniques are conventionally 
segmented steel and wood systems, pneumatically supported and modeled formworks and combinations of them (German Patent, 1990; European Patent, 1987).

Close examinations of the production of double-curved concrete-lightweight-elements based on flexible formwork systems made from GFRP are yet to come. The focus of this research work is on the numerical calculation and experimental verification of flexible, anisotropic GFRP formworks and the production of prototypical double-curved concrete-lightweight-elements with integrated stabilizing spacer fabric.

\section{Material and Methods}

\subsection{Components for Glass-Fibre Reinforced Plastic}

The unidirectional (UD) reinforced fabric UT-E500 by GURIT Holding AG was used for the production of the GFRP formwork. UT-E500 consists of aluminoborosilicate ("E glass") and has an area density of $500 \mathrm{~g} / \mathrm{sqm}$. For the thermosetting resin matrix, the epoxy resin Epilox ${ }^{\circledR}$ T19-27 by LEUNA-Harze GmbH was used. By means of manual laminating, UD single layers were made from the UD fabric and the epoxy resin. They had a fibre volume content of $30 \%$. Within this UD single layer, the independent parameters: longitudinal $\left(E_{1}\right)$ and transverse $\left(E_{2}\right)$ moduli of elasticity, Poisson's ratio $v_{12}$, shear modulus $G_{12}$ and the coefficients of linear thermal expansion $\alpha_{1}$ and $\alpha_{2}$ between +20 and $+120{ }^{\circ} \mathrm{C}$ were determined experimentally. Table 1 shows the results of these tests.

Table 1. Parameters of the unidirectional single layer

\begin{tabular}{cccccc}
\hline $\mathrm{E}_{1}$ & $\mathrm{E}_{2}$ & $v_{12}$ & $\mathrm{G}_{12}$ & $\alpha_{1(20 / 120)}$ & $\alpha_{2(20 / 120)}$ \\
$\mathrm{GPa}$ & $\mathrm{GPa}$ & - & $\mathrm{GPa}$ & $10^{-6} \cdot \mathrm{K}^{-1}$ & $10^{-6} \cdot \mathrm{K}^{-1}$ \\
\hline 23.7 & 6.4 & 0.3 & 1.6 & 7 & 130 \\
\hline
\end{tabular}

\subsection{Adjustment and Determination of Defined Curvatures}

The determined basic parameters of the unidirectional single layer (Table 1) were used for the analytical and numerical calculation of multi-layered formworks, which showed both a balanced symmetrical and an asymmetrical construction. The GFRP formwork with a plate size of $50 \times 50 \mathrm{~cm}^{2}$ was made of $11 \mathrm{UD}$ single layers with total thickness of $3.3 \mathrm{~mm}$ (Figure 1).

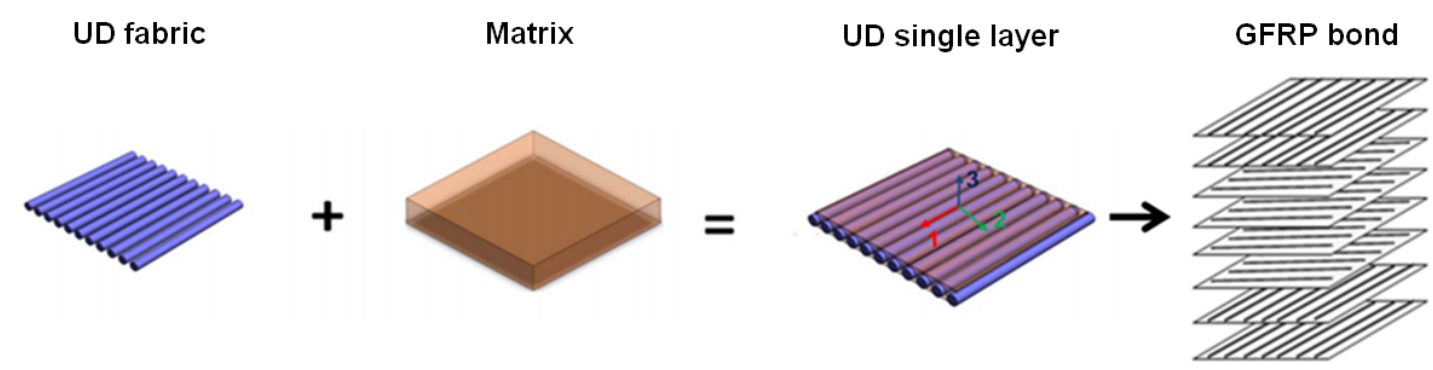

Figure 1. Process chain of anisotropic GFRP layered bond structures

After the production of the GFRP bond, the thermosetting matrix was cured in a heating cabinet over a period of 6 hours at a constant temperature of $120^{\circ} \mathrm{C}$. After curing, the GFRP bond were cooled to room temperature $\left(20^{\circ} \mathrm{C}\right)$. Due to this difference in temperature of $-100 \mathrm{~K}$, residual stress caused a small curvature of the anisotropic layer structure. Afterwards, high curvatures were caused by external preloading (up to a material load of $\mathrm{R}=0.95$ after CUNTZE criterion), utilizing the coupling effects that result from the GFRP bond (Figure 2). 
Anisotropic GFRP compound

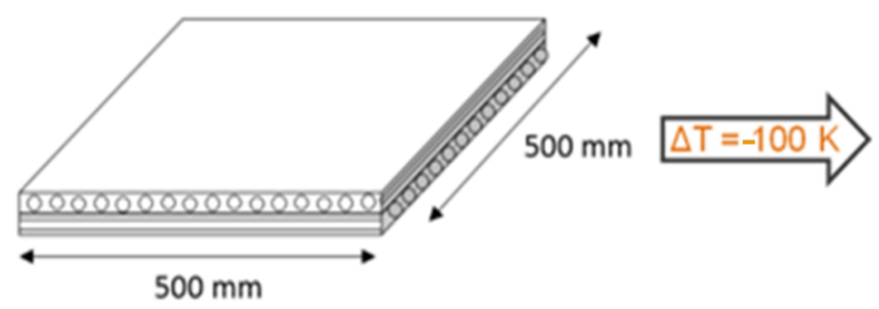

External tensile loading

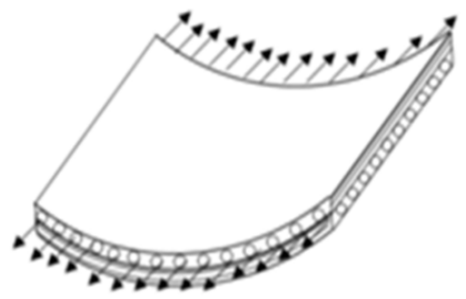

Figure 2. Temperature and tensile load of anisotropic GFRP layered bond structures for the adjustment of curvature states

The calculations of the coupling effects caused by anisotropy were conducted analytically with the Classical Laminate Theory (CLT) and the First Order Shear Deformation Theory (FSDT). For the experimental verification of the anisotropic coupling effects calculated beforehand, selected GFRP bonds segments were produced and tested in the institute's own structural test bench with the ABD-testing device (Figure 3).

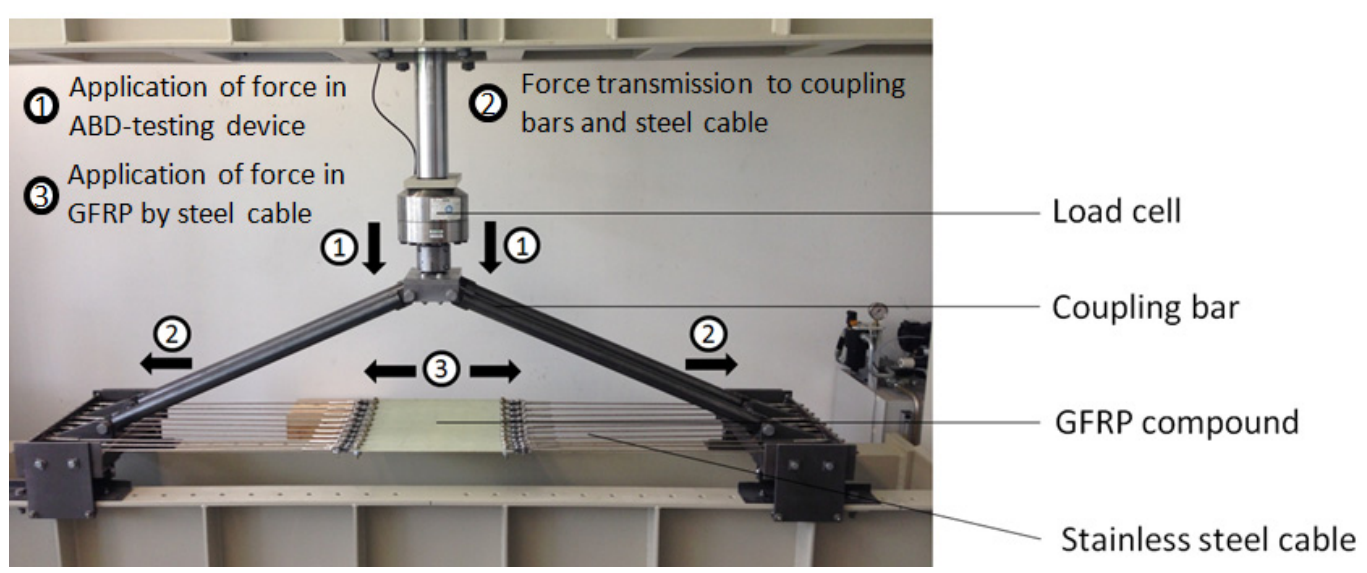

Figure 3. ABD-testing device

The results were used during the further procedure for the determination of the functional relations of curvatures, process parameters and geometrical parameters. Based on that, the analysis and identification of single and double curved basic forms was conducted. Their combination resulted in a maximum of defined freeform surfaces.

The experimental analysis of the curves was conducted with the aid of the optical forming-analysis-systems ARGUS and ARAMIS by GOM (Figure 4).
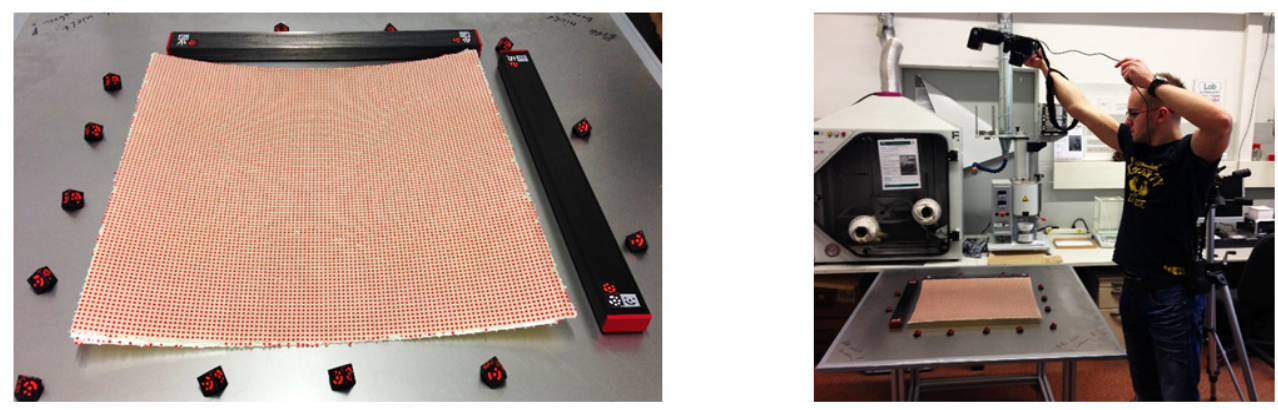

Figure 4. Curved GFRP layered bond structure plate with coded reference mark (picture on the left) and test set-up of the optical forming-analysis-system ARGUS (picture on the right) 


\subsection{Polymer-Bound Stabilization of 3D Spacer Fabrics for the Integration Into Concrete}

For the production of the textile reinforced concrete elements, the textile 3D-fabric "SITgrid" by V. Fraas Solutions in Textile GmbH was used. It is made from alkali-resistant glass (AR glass), with 2400 tex in warp and weft (Figure 5), which had a tensile strength of $978 \mathrm{MPa}$. The fabric was placed on the formwork elements to show and stabilize the curvatures accurately. Thermosetting and thermoplastic resin systems were used for the stabilization. The resin systems were applied by spraying, rolling or by using of capillary effect of the pile thread on the pre-curved 3D-fabric. By means of the Fourier transform infrared spectroscopy with attenuated total reflection (ATR-FTIR), the impact of the pile thread on capillary suction with the epoxy resin Indufloor-IB1240 of the company SCHOMBURG GmbH could be studied. For this purpose the ATR-FTIR testing apparatus ALPHA-P by BRUKER DALTONIK GmbH was used.

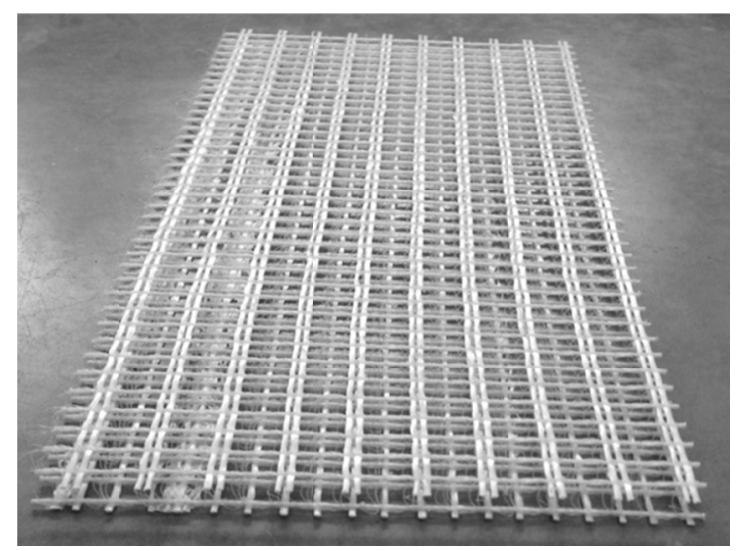

Figure 5. 3D-fabrics "SITGrid" by V. Fraas Solutions in Textile GmbH

\subsection{Textile Reinforced Concrete}

The development of the fine grained concrete was focused on the workability of the fresh concrete as well as the durability and good bonding between concrete matrix and textile reinforcement.

Table 2. Composition of the fine grained concrete mix

\begin{tabular}{lcc}
\hline Component & Content in $\mathrm{kg} / \mathrm{m}^{3}$ & Mass fraction in \% \\
\hline White cement CEM I 52.5 R & 500 & 21,39 \\
Amorphous aluminosilicate & 150 & 6,42 \\
Dolomite sand 0,5/1,0 $\left(\mathrm{x}_{50}=0,71 \mathrm{~mm}\right)$ & 1270 & 54,32 \\
Dolomite filler $\left(\mathrm{x}_{50}=70 \mu \mathrm{m}\right)$ & 150 & 6,42 \\
Water & 240 & 10,27 \\
AR-glass fibres $(12 \mathrm{~mm}$, integral $)$ & 18 & 0,77 \\
superplasticizers & 10 & 0,43 \\
\hline
\end{tabular}

Table 2 shows the qualitative and quantitative composition of the fine grained concrete mix. Apart from white Portland cement type $52.5 \mathrm{R}$, the fine concrete contained an amorphous aluminosilicate as puzzolanic binder (Table 2). Dolomite sand with a grain size of 0,5 to $1,0 \mathrm{~mm}$ was used as aggregate and dolomite powder with an average grain size of $70 \mu \mathrm{m}$ was used as filler. The alkali-resistant (AR) short glass fibres $\left(16 \mathrm{M}\right.$.- $\left.\% \mathrm{ZrO}_{2}\right)$ were 12 $\mathrm{mm}$ long and had a length mass of 45 tex. The high-performance superplasticizers had a polycarboxylate ether (PCE) contentof 30 M.- $\%$. The water-cement-ratio was 0.37 .

The fine grained concrete was mixed with the intensive mixer Eirich R05T. The mixing parameters are shown in Table 3. 
Table 3. Mixing parameters for the production of fine concrete

\begin{tabular}{lcccc}
\hline & component & mixing principle & mixing power in \% & mixing time in s \\
\hline 1. & binders + aggregates & counter rotation & 15 & 60 \\
2. & $75 \%$ of water & co-rotation & 50 & 90 \\
3. & super plasticizer & co-rotation & 50 & 60 \\
4. & residual water & co-rotation & 50 & 30 \\
5. & ar-glass fibres & co-rotation & 60 & 60 \\
\hline
\end{tabular}

The mixing time was $5 \mathrm{~min}$ in total. The fresh concrete was tested according to DIN EN 12350. Air content and bulk density of the fresh concrete were determined by means of an air content testing device, following DIN 18555-2.

\subsection{Test Specimens and Test Set-P for TRC}

The samples for the tests to be performed on the hardened concrete were stored dry, according to DIN EN 12390-2. The 3-point bending tensile strength (Figure 6a) was determined by means of the Toni Technik ToniNorm with samples which measured $225 \times 50 \times 15 \mathrm{~mm}^{3}$ (length $\mathrm{x}$ width $\mathrm{x}$ height), based on DIN EN 12390-5. The span width set was $200 \mathrm{~mm}$ and the load speed $100 \mathrm{~N} / \mathrm{s}$ constant. The compressive strength was determined by means of the Toni Technik ToniNorm (load frame $3000 \mathrm{kN}$ ) following DIN EN 12390-3, with cubes having an edge length of $150 \mathrm{~mm}$ (Figure 6b). The pre-load was $18 \mathrm{kN}$.

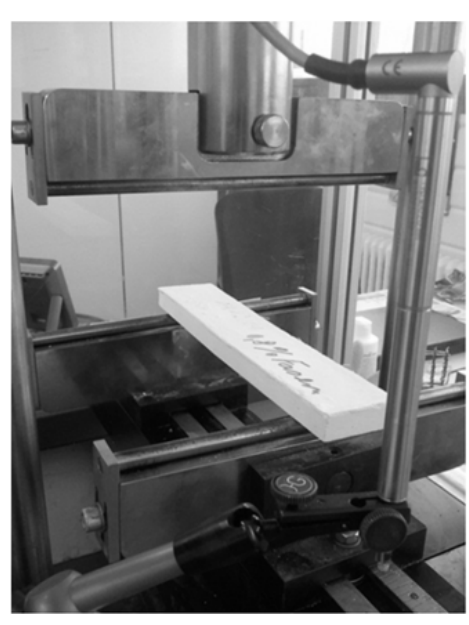

(a) 3-point bending tensile strength

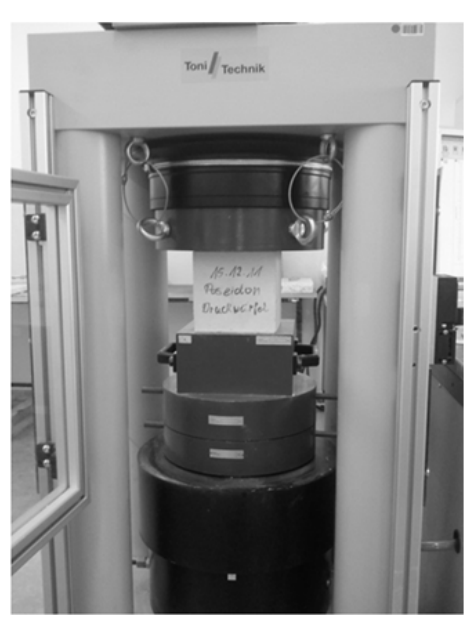

(b) compressive strength

Figure 6. Determination of 3-point bending tensile strength (a) and compressive strength(b)

To validate the durability of the fine grained concrete, the capillary suction of de-icing solution and freeze thaw test (CDF-Test) was measured by the Schleibinger Freeze-Thaw-Tester with standard agent solution according to the recommendations of RILEM TC 117-FDC.

\subsection{Production Tests GFRP Formworks/Concrete-Lightweight-Elements}

Selected representative freeform surfaces, double-curved with different radii of curvature, were produced in the production tests for the system structure GFRP formworks/concrete-lightweight-elements. The adjustment of the curves is carried out via the new flexible GFRP formwork elements. The basic proceeding when conducting the production tests comprised the production of the flexible formwork with reference curvature or preload curvature. After the production of the formwork, the spacer (Figure 7a) of the reinforcement was positioned and the spacer fabric was installed, fixed and stabilized (Figure 7b). After positioning and stabilizing the textile 3D reinforcement structure from Figure 5, the fine concrete was laminated (Figure $7 \mathrm{~b}$ ), using the adapted concrete composition displayed in Table 2. 


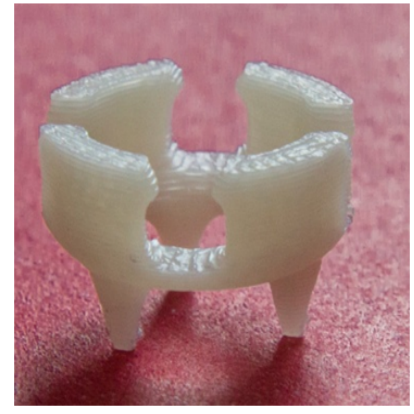

(a) textile spacer

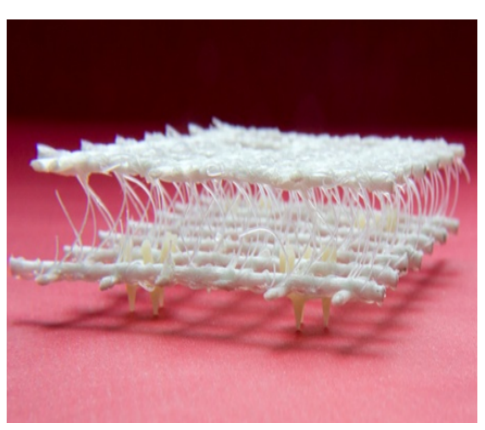

(b) spacer fabric with texile spacer

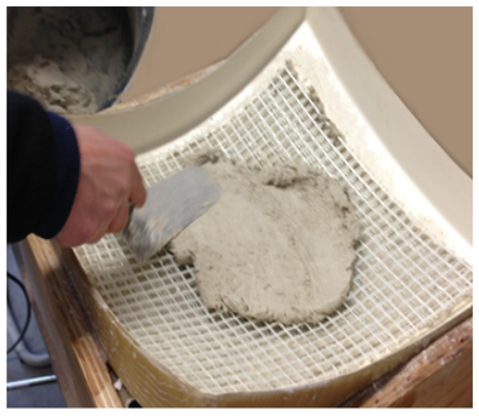

(c) application of fine grained concrete

Figure 7. Production test of the curved textile reinforced concrete elements (right)

\section{Results}

\subsection{Theoretical and Experimental Verification of Major Curves}

The theoretical major curves (for calculation approach cf. (Kroll, 2005)) of an asymmetrical layer structure with $0^{\circ}$ - and $90^{\circ}$-layer content $\left(90_{\mathrm{n}} / 0_{\mathrm{m}}\right)$ are exemplarily depicted for two loading cases in Figure 8, dependent on the $0^{\circ}$-layer content. The curves increased with increasing layer content accompanied by increasing anisotropy, both in the 1 - and in the 2-axis (Figure 8).

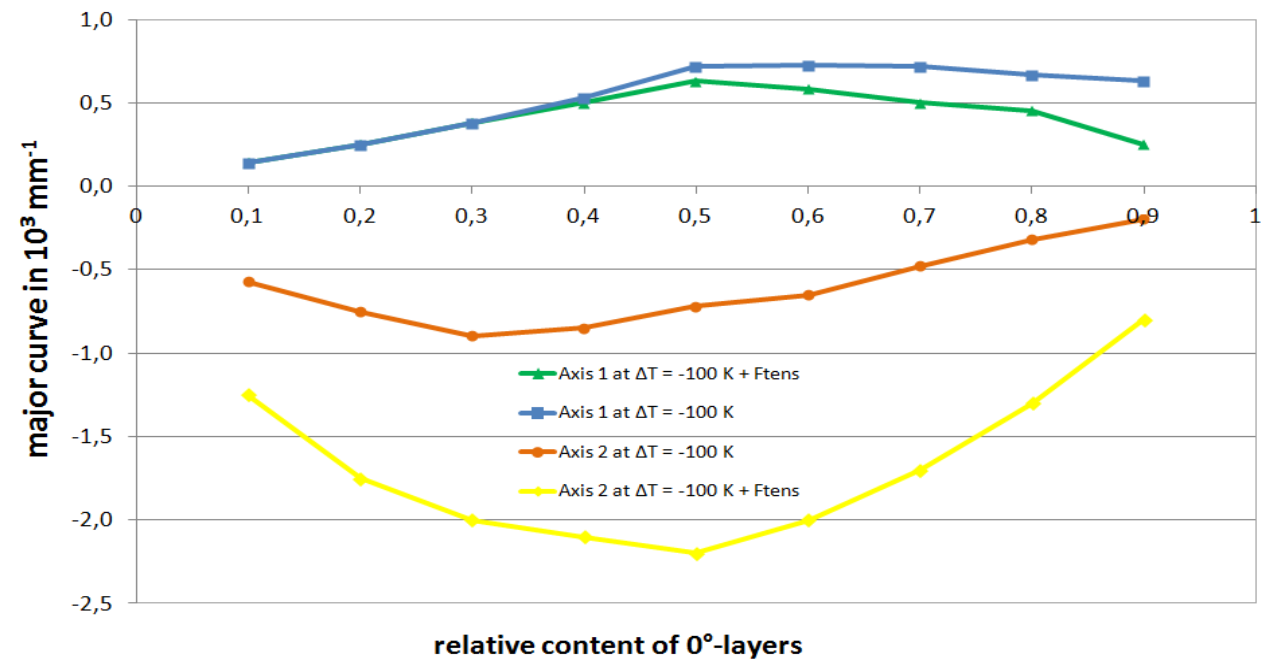

Figure 8. Theoretical major curve of an asymmetrical layer structure $\left(90_{\mathrm{n}} / 0_{\mathrm{m}}\right)$, depending on the portion of $0^{\circ}$-layer, with pure temperature load $(\Delta \mathrm{T}=-100 \mathrm{~K})$ and superimposed temperature and tensile load

The highest anisotropy was found with a relative $0^{\circ}$-layer content of about 50 percent. This caused the largest curvature around both axes (Figure 8 and 9). A further increase of the $0^{\circ}$-layer content caused a decrease of curvature, because the anisotropy of the GFRP layered bond structure decreased. Due to external preload forces, the tensile load caused an increase of curvature around the 2-axis. At the same time, curvature around the 1-axis decreased, due to traction. 


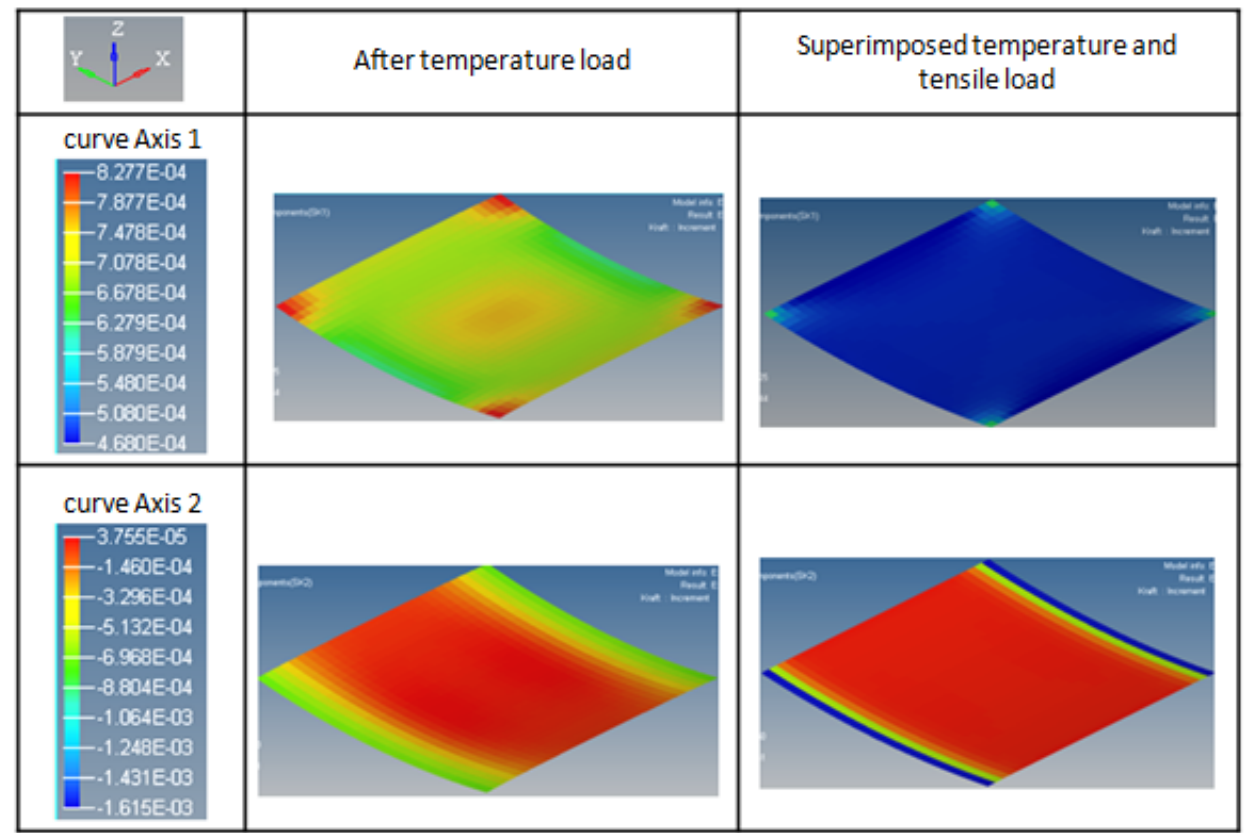

Figure 9. Theoretical major curve of the asymmetrical layer structure $90_{5} / 0_{6}$ depending on the portion of $0^{\circ}$-layer, with pure temperature load $(\Delta \mathrm{T}=-100 \mathrm{~K})$ and superimposed temperature and tensile load

Figure 10 displays the theoretical and experimentally verified major curves of the asymmetrical layer structure $\left(90_{\mathrm{n}} / 0_{\mathrm{m}}\right)$, depending on $0^{\circ}$-layer content with a pure temperature load of $(\Delta \mathrm{T}=-100 \mathrm{~K})$. The major curves around the 1-axis that were determined experimentally agreed qualitatively and approximately also quantitatively with the major curve that was calculated previously (Figure 10). The minor quantitative differences between the calculated and the experimentally verified major curves around the 1-axis were caused by physico-chemical reactions of the thermosetting matrices. In the calculations, these matrices could be included only insufficiently. Apart from chemical shrinkage, they included residual stress caused by swelling after increased water absorption in or among the molecular chains of the thermosetting matrices (Schürmann, 2007).

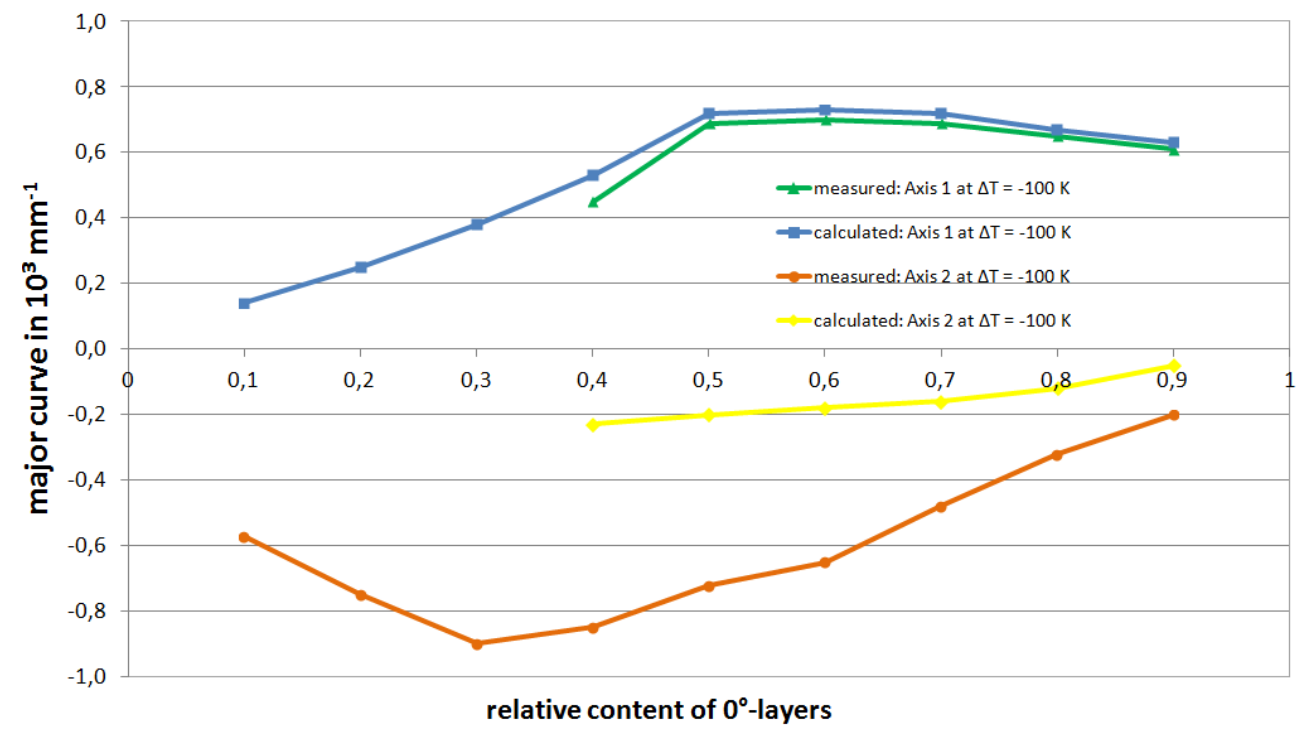

Figure 10. Comparison between calculated and experimentally verified major curvatures at $\Delta \mathrm{T}=-100 \mathrm{~K}$ 
In contrast to that, there are greater differences between the calculated and experimentally verified major curves around the 2-axis. In reality however, only one of the major curves prevails, due to stability problems (problems with the transmission/distribution of forces). In this case, this is the curvature around the 1-axis.

\subsection{Polymer-Bound Stabilization of 3D-Fabric}

Technique and technology from textile manufacturing had an influence on shape through coating with a thermosetting resin system. Mechanical characteristics were adapted to the variety of shapes and drapery. This resulted in an exact contour adapting (Figure 11a). Reverse deformation was less than 5 percent one day after the stabilization (Figure 11b). Thus, an exact depiction of the curvature state could be ensured.

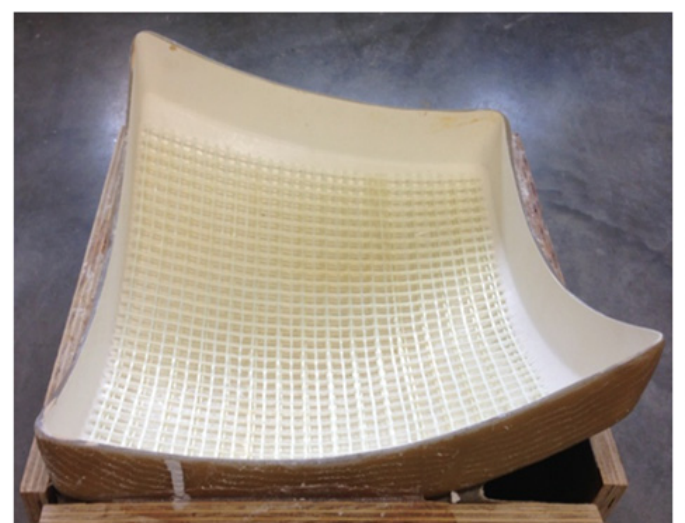

(a) flexible 3D-fabric in curved GFRP formwork

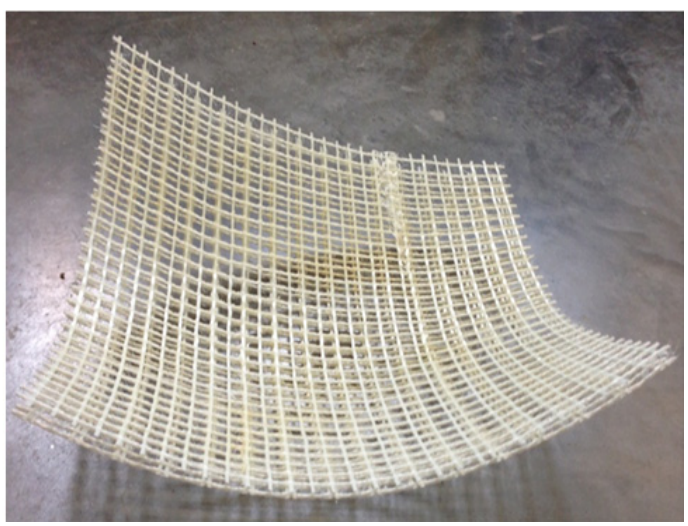

(b) stabilized 3D-fabric

Figure 11. Polymer-bound stabilization of 3D-fabrics with a thermosetting resin system

Further production studies aimed on an additional stabilization with the cold-setting epoxy resin Indufloor-IB1240 by using of the capillary effect of the pile threads. However, it was not possible to prove an increase in stiffness of the 3D-fabric, due to the insufficient capillary effect of the spacer threads (Figure 12). That can be recognized on the sample "pile thread without epoxy resin contact", which had no common quantitative characteristic peaks with the sample "epoxy resin". As opposed to this, the sample "pile thread with epoxy resin contact" had a high quantitative and qualitative peak alignment with the sample „epoxy resin" (Figure 12).

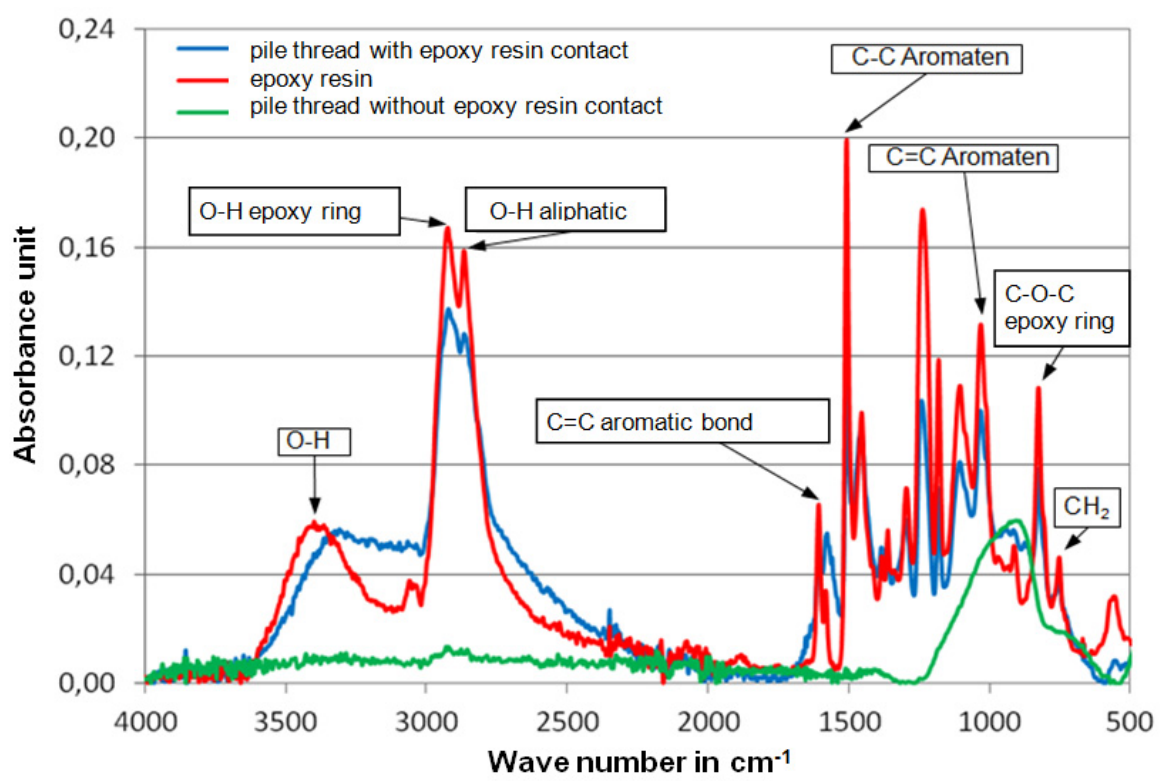

Figure 12. Fourier transform infrared spectroscopy with attenuated total reflection for the validation of polymer-bound stabilization of 3D-fabric 


\subsection{Properties and Production Tests of Concrete Lightweight Elements}

Table 3 shows the characteristics of fresh concrete and hardened concrete after 28 days. In the fresh concrete, an air content of $2.5 \%$ by volume and a geometrical density of $2.32 \mathrm{~g} / \mathrm{cm}^{3}$ were found by the use of an air entrainment meter. The total shrinkage deformation, measured with a shrinkage drain, was $0.71 \mathrm{~mm} / \mathrm{m}$. The compressive strength and 3-point bending tensile strength were 109.3 MPa and 14.74 MPa respectively. For the textile reinforced concrete, a 3-point bending tensile strength of 41.51 MPa was measured. The fine grained concrete showed a high durability, which was validated in the CDF-Test $\left(\mathrm{m}_{28}=1172 \mathrm{~g} / \mathrm{m}^{2}\right.$ and $\left.\mathrm{R}_{\mathrm{u}, 28}=100 \%\right)$ after 28 freeze-thaw cycles.

Table 3. Characteristics of fresh and hardened fine grained concrete after 28 days

\begin{tabular}{lcc}
\hline characteristic & fresh concrete & hardened concrete \\
\hline geometric bulk density & $2.32 \mathrm{~g} / \mathrm{cm}^{3}$ & $2.24 \mathrm{~g} / \mathrm{cm}^{3}$ \\
\cline { 2 - 3 } $\begin{array}{l}\text { air content } \\
\text { linear shrinkage }\end{array}$ & $2.5 \mathrm{Vol.} \%$ & - \\
\cline { 2 - 3 } $\begin{array}{l}\text { compressive strength } \\
\text { 3-point bending tensile } \\
\text { strength }\end{array}$ & $0.71 \mathrm{~mm} / \mathrm{m}$ & $0.71 \mathrm{~mm} / \mathrm{m}$ \\
\cline { 2 - 3 } & - & $109.3 \mathrm{MPa}$ \\
CDF-Test & - & $14.74 \mathrm{MPa}$ \\
& - & $\mathrm{m}_{28}=1172 \mathrm{~g} / \mathrm{m}^{2}$ \\
& & $\mathrm{R}_{\mathrm{u}, 28}=100 \%$ \\
\hline
\end{tabular}

Of special importance during the production tests was to ensure the evenness of the concrete layer thickness, consistently good surface quality, sufficient stability of the GFRP formwork and to avoid critical cracks both in the concrete and in the formwork system. Also essential were good sheeting qualities (Figure 13).

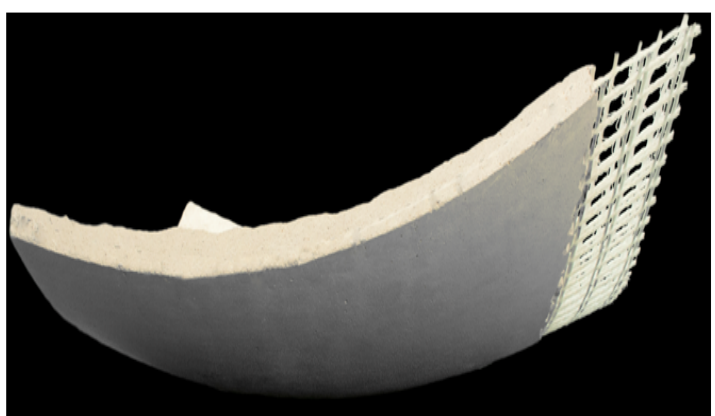

(a) Double-curved textile reinforced concrete sample

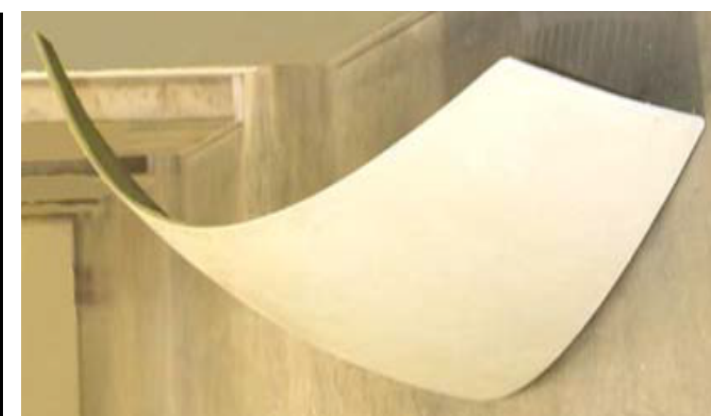

(b) demonstrator (surface area: about 3.5 square meter)

Figure 13. Production tests of concrete lightweight elements

\section{Conclusions}

The aim of this research project was to develop a flexible, multi-layered formwork system made from glass-fibre reinforced plastic, which allows for a specific adjustment of defined curvature states, utilizing the structural behavior influenced by anisotropy. The adjustment of the coupling effects, which are induced by anisotropy, were calculated in advance analytically by means of the extended laminate theory and numerically by means of the Finite Element Method. A good correspondence of the respective results for the representative shell structures was proven. An experimental verification of these intrinsic coupling phenomena has been conducted with specifically produced textile reinforced concrete-lightweight-elements. Based on the yielded results, ideal layer constructions for the key curvature states and their variation range could be set. Beyond the efficient production of curved concrete-lightweight-elements, GFRP formworks employ excellent concrete qualities on highest classes of face concrete. This contributes to the generation of new forms of architecture and buildings. The intensively conducted numerical, technological and experimental tests show that combinations of concrete and stabilizing spacer fabrics 
permit the implementation of single and double curved, multi-axially loaded surface structures. Furthermore, the flexible GFRP formwork design allows not only a location-independent implementation of freeform surfaces following the principle "form follows form" but also results in thin-walled and thus extremely light concrete shell structures.

\section{Acknowledgements}

This work was supported by the Priority Program SPP 1542 of the German Research Foundation (DFG). The authors would like to acknowledge with gratitude the foundation's financial support.

\section{References}

Brameshuber, W. (2006). Textile Reinforced Concrete, RILEM Report 36. State-of-the-Art Report of RILEM Technical Committee, TC 201-TRC.

Curbach, M., \& Jesse, F. (2010). Verstärken mit Textilbeton. In K. Bergmeister, F. Fingerloos, \& J.-D. Wörner (Eds.), Betonkalender 2010, Teil 1, Abschn. VII. Berlin: Ernst \& Sohn.

Curbach, M., \& Scheerer, S. (2011). Concrete light-Possibilities and Visions. In V. Šrůma (Ed.), Proceedings of the fib Symposium Prague 2011: Concrete Engineering for Excellence and Efficiency (pp. 29-44). 8.-10. June, DVD-ROM.

Curbach, M., Ortlepp, S., Brückner, A., Kratz, M., Offermann, P., \& Engler, T. (2003). Entwicklung einer großformatigen, dünnwandigen, textilbewehrten Fassadenplatte. Z. Beton- und Stahlbetonbau, 98(6), 345-350.

Dallinger, S., Pardatscher, H., \& Kollegger, J. (2009). Zweifach gekrümmte Schalen aus Betonfertigteilen. Z. Forschung \& Entwicklung für Zement und Beton, 5, 32-33.

DE 3841579 A1: Schalung für großformatige gekrümmte Stahlbetonfertigteile, Werner Zapf KG. Zapf, W., 1990

EP 0238168 A1: Verfahren und Vorrichtung zum Formen von gebogenen Sektionen aus Beton, Henri, V., 1987

Funke, H., Gelbrich, S., \& Ehrlich, A. (2013). Development of a new hybrid material of textile reinforced concrete and glass fibre reinforced plastic. In W. A. Hufenbach, \& M. Gude (Eds.), Procedia Materials Science. Materials Science Engineering, Symposium B6 - Hybrid Structures (Volum 2, pp. 103-110).

Funke, H., Gelbrich, S., Ehrlich, A., \& Kroll, L. (2014). A Fibre-Reinforced Architectural Concrete for the Newly Designed Façade of the Poseidon Building in Frankfurt am Main. Journal of Materials Science Research, 3(3), 33-39. http://dx.doi.org/10.5539/jmsr.v3n3p33

Funke, H., Gelbrich, S., Ehrlich, A., Kroll, L. (2014). Rheological and mechanical development of a fiber-reinforced concrete for an application in civil engineering. SOJ Materials Science \& Engineering, 2(2). http://dx.doi.org/10.15226/sojmse, ISSN (online) 2372-0964, p. 1-4, 2014a.

Greiner, S. (2007). Zum Tragverhalten von Schalen aus ultrahochfestem Faserfeinkornbeton (UHFFB). Z. Betonund Stahlbetonbau, 100(9), 77-80.

Herzog, T., \& Moro, J. L. (1992). Gespräch mit Felix Candela. In Arcus 18: Zum Werk von Felix Candela - Die Kunst der leichten Schalen (pp. 10-22). Köln: Verlagsgesellschaft Rudolph Müller.

Hofstadler, C. (2008). Schalarbeiten. Berlin, Heidelberg: Springer-Verlag.

Kaufmann, J. (2014). Beitrag zu anisotropiebedingten Koppeleffekten bei rotationssymmetrischen mehrschichtigen Faserverbundbauteilen. Promotionsschrift, TU Chemnitz.

Kroll, L. (2005). Berechnung und technische Nutzung von anisotropiebedingten Werkstoff - und Struktureffekten für multifunktionale Leichtbauanwendungen. Habilitationsschrift, TU Dresden.

Preisinger, C., Harrer, J., Ressl, C., \& Kollegger, J. (2005). Stahlbetonschalen ohne Schalung - ein neuer Weg im Schalenbau. Beton- und Stahlbetonbau 100, 31-38.

SCHÜRMANN, H. (2007). Konstruieren mit Faser-Kunststoff-Verbunden. New York: Springer Verlag Berlin Heidelberg.

\section{Copyrights}

Copyright for this article is retained by the author(s), with first publication rights granted to the journal.

This is an open-access article distributed under the terms and conditions of the Creative Commons Attribution license (http://creativecommons.org/licenses/by/3.0/). 